\title{
MADURA DEVELOPMENT PLAN AS A DESTINATION SYARIAH INDONESIA TOURISM
}

\author{
${ }^{1}$ Sutikno, ${ }^{2}$ Ahmad Kamil, ${ }^{3}$ Mohd Shukri Hanapi \\ ${ }^{12}$ Economic and Business Faculty, Trunojoyo University Madura, Indonesia \\ Jl. Taya Telang PO.Box 2 Kamal, Bangkalan \\ ${ }^{3}$ Centre for Islamic Development Management Studies (ISDEV) \\ Universiti Sains Malaysia, 11800 USM,Penang, Malaysia \\ sutikno@trunojoyo.ac.id
}

\begin{abstract}
This study aims analyze the potential of attractions in Madura to become sharia tourism destinations. Next will measure the level of community readiness and development strategies for Islamic tourism in Madura. To analyze the potential of sharia tourism objects, they use observational analysis and public perceptions about the suitability of tourism objects with sharia tourism. As for the analysis of the development of Islamic tourism on the island of Madura using the Analytical Hierarchy Process method. The results showed that, Madura has the potential to become a sharia tourist destination, because has a potential tourist attraction to be developed into an Islamic tourist attraction. Second, the Madurese people already have an understanding of sharia tourism, this will be a big capital for Madura to become sharia tourism destinations in Indonesia. Citizen Branding Strategy can be a top priority in efforts to develop Islamic tourism on the island of Madura.
\end{abstract}

Keywords: Sharia Tourism, Development , Madura

\section{Introduction}

The Ministry of Tourism has established 13 provinces in Indonesia that are prepared to become sharia tourist destinations, namely West Nusa Tenggara (NTB), Nangroe Aceh Darussalam, West Sumatra, Riau, Lampung, Banten, DKI Jakarta, West Java, Central Java, Yogyakarta, East Java, South Sulawesi, and Bali (Indonesia Travel, 2013). The Sharia tourism destination is determined based on the readiness of human resources, community culture, regional tourism products, and tourist accommodation.
Based on the social characteristics of society should Madura including East Java Province with the most potential to become a tourist destination Indonesian sharia. This, because the eyes of the public national identi Madura is a region with the characteristics of his Islam. However, the characteristics or identity of Madura as an Islamic region or even having the nickname "Serambi Madina" does not guarantee Madura has competitiveness and resource readiness, community culture, regional tourism products, and tourist accommodation to

Received: 2019-12-02 | Reviced: 2020-01-08 | Accepted: 2020-01-31

Indexed : Sinta, DOAJ, Garuda, Crossref, Google Scholar | DOI: https://doi.org/10.29313/amwaluna.v4i1.5390 
Sutikno, Ahmad Kamil, Mohd Shukri Hanapi, Madura Development Plan As A Destination Syariah Indonesia...

support the development of Islamic tourism in Madura.

Therefore, we need a research that is able to map the potential of sharia tourism destinations in Madura and measure the understanding of Madurese people towards sharia tourism and plans and strategies for developing Madura to become sharia tourism destinations in Indonesia. Based on this needs, this research formulates the objectives : (a) Describe the potential of sharia tourism destinations in four districts on the island of Madura; (b) Analyzing the perception of the Madurese community towards Sharia tourism on the island of Madura; (c) Analyze the planned development of Madura as an Indonesian sharia tourism destination.

\section{Discussion}

\section{A. Foundation Theory}

According to (Sofyan, 2012)( Permadi, L. A., Darwini, S., Retnowati, W., Negara, I. K., \& Septiani, E, 2018), the definition of sharia tourism is broader than religious tourism, namely tourism based on Islamic sharia values. As recommended by the World Tourism Organization (WTO), consumers of sharia tourism are not only Muslims but also non-Muslims who want to enjoy local wisdom. The Sofyan Hotel network owner explained, the general criteria for sharia tourism are; first, have an orientation to the public good. Second, have an orientation of enlightenment, refreshment, and calmness. Third, avoid polytheism and khurafat. Fourth, free from immorality. Fifth, maintain safety and comfort. Sixth, protecting the environment. Seventh, respect for socio-cultural values and local wisdom. In addition to the term sharia tourism, also known as Halal tourism.

At the launch of sharia tourism which coincided with the 2013 Indonesia Halal Expo (Indhex) activity and the Global Halal Forum, President of the Islamic Nutrition Council of America, Muhammad Munir Caudry, said that, "Halal tourism is a new concept of tourism. This is not religious tourism such as Umrah and pilgrimage. Halal tourism is tourism that caters to holidays, by adjusting the vacation style to suit the needs and demands of a Muslim traveler. In this case hotels that carry the principles of sharia do not serve alcoholic drinks and have separate swimming pools and spa facilities for men and women (Wuryasti, 2013).

According to Pavlove in Razzaq, Hall and Prayag, Halal or Islamic tourism is defined as tourism and hospitality which are also created by consumers and producers in accordance with Islamic teachings. Many countries in the Islamic world are taking advantage of the 
increasing demand for Muslim-friendly travel services (Razzaq, Hall, and Prayag, 2015).

While Demeiati Nur Kusumaningrum's research results (2017), regarding South Korean Halal Tourism Trend, shows the results of her research that the interests of South Korea to build an image of a Muslim-friendly country by considering the following matters: 1) increasing people's income and investment, 2) looking for alternatives development of the domestic market so as not to depend on China as an export destination, and 3) strengthen cooperation and diplomatic relations with non-traditional countries.

\section{B. Research Methods}

Based on the objectives, this research is a descriptive study using a quantitative approach. This research will describe the potential of every tourist attraction on the island of Madura to be developed into an Islamic tourist attraction based on public perception.

In this study the population is unknown, so to facilitate the determination of the number of samples taken is determined by the formula (Riduwan, 2004): $n=0.25(Z \alpha / 2 \varepsilon)^{2}$

Where: $\mathrm{N}=$ number of samples; $\mathrm{Z} \alpha / 2=$ value obtained from the normal table for the level of confidence; $\varepsilon=$ sampling error. The level of confidence in this study was determined at $95 \%$, then the value of $\mathrm{Z}_{\alpha / 2}$ was 1.96 .

The sampling error rate is set at $10 \%$. Then from the calculation of the formula, it can be obtained the samples needed for each district, namely: $n=0.25$ $(1.960 .1)^{2}, n=96.04$. So based on the formula above, the sample taken was 96.04 people multiplied by four districts, totaling 400 people.

There are two measurement variables in this study, namely

Attraction and, (2) Amity. Of each variable is determined sub variables and indicators for each - each sub variables. Assessment of indicators uses intervals with Strongly Agree (SA), Agree (A), Doubtful (D), Disagree (DA), and Strongly Disagree (SD). Data analysis techniques using data quality testing.

Whereas to plan the development of Islamic tourism in Madura, the Analytical Hierarchy Process (AHP) method is used. This method is a decision support model developed by Thomas L. Saaty whose decision will break down complex multi-factor or multi-criteria problems into one hierarchy.

C. Result And Discussion

\section{a. Potential Sharia Tourism Destinations} in Madura

The results of this study resulted in two findings, namely the potential of 
Sutikno, Ahmad Kamil, Mohd Shukri Hanapi, Madura Development Plan As A Destination Syariah Indonesia...

Islamic tourism objects in each district on Madura Island and the perception of the Madurese community towards Sharia tourism. These two findings will conclude whether the Madura island is ready or not ready to become a Sharia tourist destination in Indonesia.

This section will describe the results of research related to public perceptions related to the potential of attractions in each district on the island of Madura to be developed into sharia attractions. The community assessment is based on the nine characteristics of Sharia Tourism based on the DSN MUI, namely: (1) Oriented to general welfare; (2) Presentation on enlightenment, refreshment, and calmness; (3) Can avoid polytheism and khurofat ; (4) Can avoid immorality such as adultery, pornography, porn action, liquor, drugs \& gambling ; (5) Maintaining ethical behavior, noble human values such as not hedonic and immoral ; (6) Can maintain the mandate, safety, and comfort ; (7) Universal and Inclusive ; (8) Protecting the environment ; (9) Respect for socio-cultural values and local wisdom .

Madura Island is administratively divided into four districts namely Bangkalan, Sampang, Pamekasan, and Sumenep. The four districts have tourism potential that can be developed into Islamic tourism destinations. Based on the identification results show that Bangkalan Regency has 16 attractions that can be developed to become sharia attractions. Sampang Regency has 9 attracti ons that can be developed to become sharia attractions. Pamekasan Regency has 13 attr actions that can be developed to become sharia

attractions. Sumenep Regency has 21 attrac tions that can be developed to become sharia attractions.

If the attractions in each regency are seen based on nine characteristics of sharia tourism, it will be seen which characteristics are superior to each of these attractions according to public perception. The following table describes the average response of respondents based on the characteristics of halal tourism in each district in Madura .

Table 1

Characteristics of Tourism Objects in Each District

Based on the Nine Characteristics of Syriah Tourism

\begin{tabular}{|c|l|c|c|c|c|c|c|c|c|c|}
\hline \multirow{2}{*}{ No. } & \multirow{8}{*}{ districts } & \multicolumn{8}{|c|}{ Score Based Arat } \\
\cline { 3 - 12 } & & $\mathbf{1}$ & $\mathbf{2}$ & $\mathbf{3}$ & $\mathbf{4}$ & $\mathbf{5}$ & $\mathbf{6}$ & $\mathbf{7}$ & $\mathbf{8}$ & $\mathbf{9}$ \\
\hline 1 & Bangkalan & 3.93 & 3.95 & 3.81 & 3.80 & 3.87 & 3.82 & 3.89 & 3.85 & 3.94 \\
\hline 2 & Sampang & 4.05 & 3.96 & 3.83 & 3.85 & 3.89 & 3.85 & 3.87 & 3.82 & 3.90 \\
\hline 3 & Pamekasan & 3.75 & 3.61 & 3.49 & 3.56 & 3.56 & 3.51 & 3.56 & 3.57 & 3.68 \\
\hline 4 & Sumenep & 4.33 & 4.14 & 4.07 & 4.21 & 4.17 & 4.14 & 3.94 & 4.10 & 4.20 \\
\hline \multicolumn{2}{|c|}{ Average } & $\mathbf{4 . 0 2}$ & $\mathbf{3 . 9 2}$ & $\mathbf{3 . 8 0}$ & $\mathbf{3 . 8 6}$ & $\mathbf{3 . 8 7}$ & $\mathbf{3 . 8 3}$ & $\mathbf{3 . 8 2}$ & $\mathbf{3 . 8 4}$ & $\mathbf{3 . 9 3}$ \\
\hline
\end{tabular}

Source: Primary Data, processed

Tabel above explains that, attractions in Bangkalan have characteristics with the number of scores the highest average on the 
characteristics to -2 namely "Oreintation enlightenment, refreshment and tranquility " that the average respondent's answer is 3.95 , meaning that almost all of the public Bangkalan "Agree" that 16 attractions in Bangkalan "Oriented to enlightenment, refreshment, and calmness". The second advantage of tourism objects in Bangkalan Regency is in the 9th Halal criteria, namely: "Respecting social cultural values and local wisdom" with an average score of 3.94 respondents' answers, meaning that almost all Bangkalan people "Agree" that 16 the tourist attraction " Respects social cultural values and local wisdom ". While the total value of the lowest for the characteristics to -4 , namely "Can avoid immoral as adultery, pornography, sexually explicit, alcohol, drugs and gambling " with an average of 3.80 of respondents, but even the lowest figure, but the figure is approaching masi value of 4 means that almost all of the public Bangkalan, Agree that the 16 attractions of the "Can avoid immoral as adultery, pornography, sexually explicit, alcohol, drugs and gambling ".

While the characteristics of attractions in Sampang Regency based on nine criteria of sharia tourism, can be explained as follows. The highest average score value is found in the 1 characteristic, which is "Oriented to general welfare" ie the average respondent's answer is 4.05 , meaning that almost all Sampang people "Agree" that the 9 tourism objects in Sampang Regency are "Oriented to the benefit of general". The second advantage of the attractions in the district of Sampang is the criteria to-2, namely: "Oreintation enlightenment, refreshment and serenity" to score an average of 3.90 respondents, meaning that almost all societies Sampang "Agree" that 9 attractions the "Oriented enlightenment, refreshment and serenity". While the total value of the lowest for the characteristics to -8 is "Preserving the environment "with average respondents 3.80 , but although the figures were the lowest, but the figures were masi is also close to 4 means that almost all societies Sampang, Agree that 9 tourist attraction "Protect the environment .

According to the table in the above explained that, attractions in the District of Pamekasan that have a score value the highest average on the characteristics to 1 is "oriented on the general welfare " is the average respondents 3.75 , meaning that almost all of society Pamekasan "Agree" that 13 attractions in Pamekasan Regency "Oriented to general welfare ". The second advantage of tourism objects in Pamekasan Regency is in the 9th criteria, namely: "Respect social 
Sutikno, Ahmad Kamil, Mohd Shukri Hanapi, Madura Development Plan As A Destination Syariah Indonesia...

cultural values and local wisdom" with an average respondent's answer of 3.68 , meaning that almost all Pamekasan people "Agree" that the 13 attractions "Respect for socio-cultural values and local wisdom ". While the total value of the lowest for the characteristics to - 3, namely" to avoid kemusyirikan and khurofat " with an average respondents 3:49, Angaka approached 3 means people Pamekasan, Hesitate that 13 tourist attraction "to avoid kemusyirikan and khurofat ".

While the characteristics of attractions in Sumenep Regency based on nine criteria of sharia tourism, can be explained

follows. The highest average score is found in the -1 characteristic, which is "Oriented to general welfare" ie the average respondent's answer is 4.33 , meaning that almost all Sumenep people "Agree" that 21 attractions in Sumenep Regency " Oriented to general benefit ". The second advantage of tourism objects in Sumenep Regency is in the 9th criteria, namely: "Respect social cultural values and local wisdom " with an average respondent's response of 4.20, meaning that almost all Sumenep people "Agree" that the 21 attractions "Respect for socio-cultural values and local wisdom". While the total value of the lowest for the characteristics to -7 , namely "Characteristically universal and inclusive " with an average of 3.94 respondents, approached Angaka 4 means the people Sumenep, "Agree" that the 21 attractions of the "Characteristically universal and inclusive ".

\section{b. Understanding the}

\section{Madurese Against Tourism Sharia}

The level of community understanding of Sharia tourism is very necessary, because the community is one of the supporters of tourism, especially the local community. If the community understands sharia tourism, the community will help provide support facilities to serve the visitors. Thus, the tourism planned sharia in Madura one of the major capital it is the public should be aware of what tourism was sharia so that the people can help develop tourism sharia in Madura .

The results of the respondents' answers to understand whether or not about sharia tourism are measured using a Likert scale that is if the respondent answers very well understand then gets a score of 5, if the respondent answers understanding then gets a score of 4 , if the respondent answers doubtfully then gets a score of 3 , if the respondent answers do not understand then get a score of 2, if the respondent answers do not understand once then get a score of 1. One hundred respondents per district in Madura are 
sampled and counted or measured using a Likert scale, the results are:

$$
\begin{aligned}
\text { Me } & =\frac{\left(x \frac{400}{2}\right)+\left(x \frac{400}{2}+1\right)}{2} \\
& =(\mathrm{X} 200+\mathrm{X} 201) / 2 \\
& =(4+4) / 2 \\
& =4
\end{aligned}
$$

So the median results are as large as 4 , so that the median results of respondents' answers to the understanding of whether or not about sharia tourism is equal to 4 . So it can be concluded that the Madurese community can be said to understand about sharia tourism . With this understanding, it will become a great capital for Madura to become an Indonesian sharia tourist destination. Because based on the experience of regions that develop Islamic tourism such as West Nusa Tenggara, the trust must also have the support of the community.

The results of this study have similarities with the research conducted by Lalu Adi Permadi (2018), who examined the perceptions and attitudes of the people towards the planned development of sharia tourism (halal tourism) in West Nusa Tenggara Province (NTB). The results of his research concluded that the people of West Nusa Tenggara have a good perception of the planned implementation of halal tourism in this area. The people of West Nusa Tenggara have a positive attitude towards the planned implementation of halal tourism in this area. From the Cartesian diagram it is known that the results of the planned implementation of halal tourism are perceived and responded very highly by the NTB community.

\section{c. Analysis of Syraiah Tourism Development in Madura}

Analysis of the development of Islamic tourism in Madura Island uses the Analytical

Hierarchy Process (AHP) method which is a decision support model developed by Thomas L. Saaty whose decision will describe the complex multi-factor or multi-criteria problem into one hierarchy. In the AHP Method, data processing begins by compiling a hierarchy based on data development criteria that will be implemented. The preparation of the hierarchy must first determine the goals or objectives, criteria, sub-criteria and alternatives in achieving those objectives. The following results of the analysis in an effort to develop Islamic tourism in Madura Island, based on the Analytical Hierarchy Process (AHP) . 


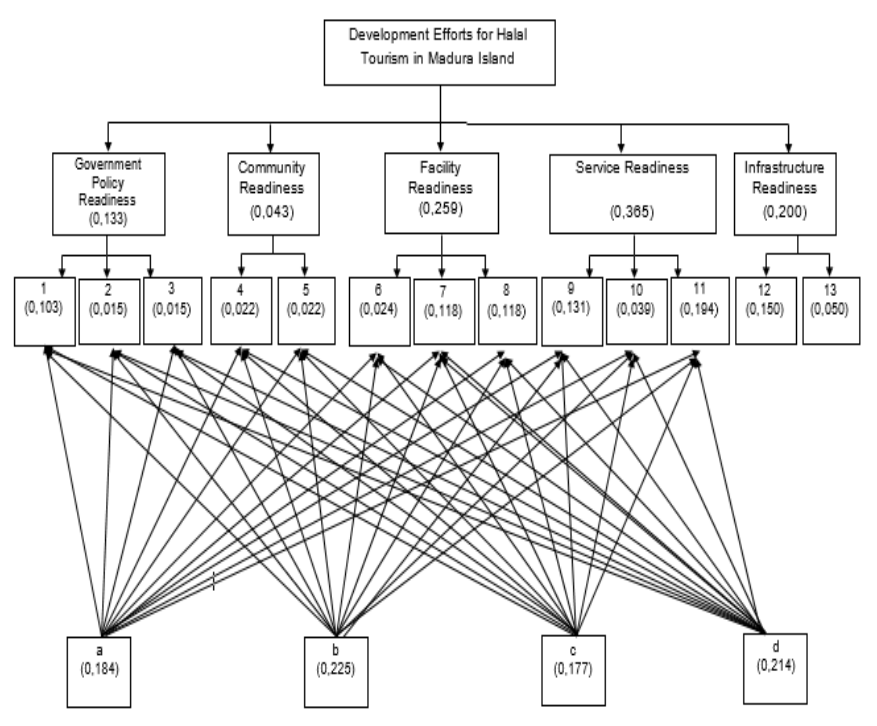

Figure 1.

Hiraki Structure Sharia Tourism

Development Policy in Madura

Information:

1. Regional Regulation

2. Promotion

3. Budget Provision

4. Understanding of

Islamic Tourism

5. Community Support

for Sharia Tourism

6. Worship Facilities

7. Accommodation

Facilities

Alternative (Output) Development:
a. Branding Products
b. Citizen Branding
c. Branding Event
d. Place Branding

Based on the results of the AHP analysis, it shows that the greatest weight of the policy that is prepared is the readiness of services consisting of: (a) Sharia Travel Bureau Services; (b) Islamic Financial Institution Services; (c) Sharia Health Services, this service readiness has a value of 0.365 . After the readiness of services is followed by the readiness of facilities which have an amount of 0.259, the readiness of the facilities in question consists of: (a) Worship Facilities; (b) Accommodation Facilities; (c) Restaurant / Restaurant. The results of this study confirm the results of previous studies by Elpa Hermawan (2019), who examined the strategy of the Indonesian tourism ministry in increasing halal tourism branding. The results of his research concluded that the Indonesian government had built three aspects of appropriate strategies to improve the quality of world-class halal tourism, namely in the aspect of destinations, by providing halal tourism facilities and services in accordance with the needs of

12. Sharia Internet Network ouslim tourists and Islamic law. Then by utilizing a digital system that can be reached anywhere easily so that travel deals can reach the international scene; as well as improving the quality of human resources both from the curriculum concept, certification to show the competencies possessed by each person or halal tourism services and also the concept of tourism offered.

In addition to the two readinesses above, to develop Islamic tourism in Madura also required several other readiness namely: infrastructure readiness with a value of 0.200 , Government policy 
readiness with a value of 0.133 , and community readiness with a value of 0.043 . The infrastructure readiness in question is (a) Sharia Internet Network and (b) Sharia Entertainment Place. Whereas what is meant by the readiness of government policies are: (a) Regional Regulations, (b) Promotion, and (c) Provision of budgets. And what is meant by community readiness is: (a) Understanding of Syraiah Tourism; and (b) Community Support for Sharia Tourism. The need for government policy in the development of sharia tourism policies in Madura, in line with the results of Rimet's research (2018), which examines sharia tourism development strategies in West Sumatra using a SWOT (Strength, Weakness, Opportunity, Threath) analysis. The results of his research conclude that the sharia tourism development strategy in West Sumatra is to make tourism a leading sector, implemented through an integrated movement of tourism development, Coordination Meetings with Provincial Governments, Regencies/Cities and Related Stakeholders, Provincial Government Agreements, Regencies/Cities making Sumatra West as Halal Wista Destinations, selection of West Sumatra as the Best National Halal Destination, selection of West Sumatra as the Best National Halal Culinary Destination, selection of West Sumatra as World's Best Halal Destination, selection of West Sumatra as World's Best Halal Culinary Destination, Socialization of Halal Tourism for Tourism Stackholders, providing subsidies for arranging Halal Certification for industry (restaurants / restaurants), compiling Halal Tourism Local Regulation.

Weight of Inter-Alternative Final Values

After knowing the weight of each alternative based on sub-criteria, then the next is to determine the overall alternative weight or find the final weight of the alternative value. How to determine the final weight between alternatives is by multiplying the weight of each subcriterion

the alternative weight. Following are the results of the calculation of the weight of the final value of each alternative policy.

Table 2

Weight of Final Value of Each Criteria and Policy Sub-Criteria

\begin{tabular}{|l|c|c|c|c|c|}
\hline Criteria/ Sub-Criteria & Weight & $\begin{array}{c}\text { Product } \\
\text { Branding }\end{array}$ & $\begin{array}{c}\text { Citizen } \\
\text { Branding }\end{array}$ & $\begin{array}{c}\text { Branding } \\
\text { Event }\end{array}$ & $\begin{array}{c}\text { Place } \\
\text { Branding }\end{array}$ \\
\hline $\begin{array}{l}\text { Government Policy } \\
\text { Readiness }\end{array}$ & .133 & & & & \\
\hline Local regulation & .103 & 0.031 & 0.005 & 0.054 & 0.013 \\
\hline Promotion & 0.015 & 0.004 & .001 & 0.007 & 0.002 \\
\hline Budget Provision & 0.015 & 0.004 & .001 & 0.008 & 0.002 \\
\hline Community Readiness & 0.043 & & & & \\
\hline $\begin{array}{l}\text { Pem ahaman Against } \\
\text { Syraiah Tourism }\end{array}$ & 0.022 & 0.006 & .001 & 0.011 & 0.003 \\
\hline $\begin{array}{l}\text { Community Support } \\
\text { For Syraiah Tourism }\end{array}$ & 0.022 & 0.007 & 0.007 & 0.006 & .001 \\
\hline Facility Readiness & .259 & & & & \\
\hline Worship Facilities & 0.024 & 0.003 & 0.014 & 0.002 & 0.005 \\
\hline Accommodation Facilities & .118 & 0.008 & 0.060 & 0.020 & 0.030 \\
\hline Restaurant / Restaurant & .118 & 0.008 & 0.060 & 0.020 & 0.030 \\
\hline Service Readiness & .365 & & & & \\
\hline Shia Travel Bureau Service & .131 & 0.066 & 0.019 & 0.033 & 0.013 \\
\hline $\begin{array}{l}\text { Islamic Financial } \\
\text { Institution Services }\end{array}$ & 0.039 & 0.020 & 0.007 & 0.004 & 0.008 \\
\hline Sharia Health Services & .194 & 0.027 & 0.050 & 0.012 & .106 \\
\hline Infrastructure Readiness & 0,200 & & & & \\
\hline Sharia Internet Network & .150 & - & - & - & - \\
\hline $\begin{array}{l}\text { Sharia Entertainment } \\
\text { Place }\end{array}$ & 0.050 & - & - & - & - \\
\hline Weighted results & & .184 & 0.225 & .177 & 0.214 \\
\hline
\end{tabular}

Source: Primary Data, processed (2019) 
Sutikno, Ahmad Kamil, Mohd Shukri Hanapi, Madura Development Plan As A Destination Syariah Indonesia...

Based on the results of the final weighting assessment of alternative priorities, a high final weighting is found in the second alternative, Citizen Branding with a weight of 0.225 so that it becomes a top priority in efforts to develop syraiah tourism on Madura Island. Then, the second highest value is found in the fourth alternative, Place Branding with a weight of 0.214 making it the second priority. After that, the third highest value is found in the first alternative, Product Branding with a weight of 0.187 . And the lowest final weight is in the third alternative, Event Branding with a weight of 0.177 , this is the fourth priority in the development of Islamic tourism on Madura Island.

So, the assessment with a paired comparison system using the Analytical Hierarchy Process (AHP) method results shows that the second alternative or Citizen Branding is the right alternative to be chosen or become the main priority because it has the highest final weighting of 0.225 .

\section{Conclusion}

Madura Island has the potential to become a sharia tourism destination for Indonesia, because Madura has a potential tourist attraction to be developed into an Islamic tourist attraction. The second reason is, Madurese people already have an understanding of sharia tourism, this will be a big capital for Madura to become sharia tourism destinations in Indonesia. CitizenBranding Strategy can be a top priority in efforts to develop Islamic tourism on the island of Madura.

Based on the findings of this potential, several Madura sharia tourism development strategies are needed as follows: (a) Conducting socialization on the concepts and objectives of the development of sharia tourism to government officials, the public and tourism (industrial) business operators in Ma dura; (b) Incorporate sharia tourism content in the PERDA concerning tourism; (c) Determine the appropriate branding related to the promotion of Manado as an Islamic tourist destination; (d) Creating a website-based Frequently Asked Questions forum as a source of information for grassroots people who want to get information about sharia tourism; (e) Promoting Madura as destination for Islamic tourism to the target market; (f) Prepare competent guides to handle Muslim tourists .

\section{Bibliography}

Achyar, Mahfud. (2015). Indonesia as a Halal Tourism Destination. Picked fromhttps://achyar89.wordpress.com :https://achyar89.wordpress.com/201 
$\underline{5 / 07 / 01 /}$ indonesia-sebagaitujuanhalal-tourism

Elpa Hermawan. (2019). Strategy of the Indonesian Ministry of Tourism in Increasing Halal Tourism Branding. Jurnal Ilmu Manajemen dan Akutansi Vol. 7, No.2, 2019. Hal 8795

Demeiati Nur Kusumaningrum, Aulia Mawaddah Fairuz ,Erima Puspita Putri, Erdina Putri Amalia. South Korean Halal Tourism Trend. National Seminar and Product Title 2017.

Dini Andriani dkk (2015). Sharia Tourism Development Study. Deputy for Tourism Institutional Development in the Ministry of Tourism.

Global Islamic Economy Report 2014-2015 Global Muslim Travel Index (GMTI) 2015 Hamzah, Maulana. M., \& Yudiana, Yudi. (2015). Comparative Analysis of the Potential of Halal Industry in Conventional and Sharia Tourism. Picked, from http://catatanek18.blogspot.co.id:http ://catatanek18.blogspot.co.id/2015/0 21 analisis-komparatifpotensiindustri. html

Kemenpar. (2012). Promote Indonesia as a World Sharia Tourism Destination. Picked from http://www.kemenpar.go.id: http://www.kemenpar.go.id/asp/detil. asp? $\mathrm{c}=16 \& \mathrm{id}=2042$

Kemenpar. (2015). Number of Foreign Tourist Visits According to Entrance and Nationality. Jakarta: Kementerian Pariwisata.

Kilinç, Akyol. \&. (2014 ). "Internet and Halal Tourism Marketing”. International Periodical For The Languages, Literature and History of Turkish or Turkic Volume 9/8 Ankara-Turkey , 171-186.

Lalu Adi Permadi, Sri Darwini, Weni Retnowati, Iwan Kusuma Negara, Emilia Septiani. (2018). Public Perceptions and Attitudes Towards Sharia Tourism Development Plan (Halal Tourism) In Provinsi Nusa Tenggara Barat. Amwaluna: Jurnal Ekonomi dan Keuangan Syariah Vol. 2 No. 1 January 2018 Page 34-53.

Master Card, \& Crescenrating. (2015). Global Muslim Tourism Index 2015. Dipetik dari www.crescenrating.com: http://www.crescenrating.com/ mastercard- $\quad$ crescenratingglobalmulsim-travel-index.html Murdaningsih, Dwi., \& Pratiwi, Fuji. (2015). Indonesian Halal Tourism Loses Compared to Malaysia and Thailand. Picked from http://www.republika.co.id/: 
Sutikno, Ahmad Kamil, Mohd Shukri Hanapi, Madura Development Plan As A Destination Syariah Indonesia...

http://www.republika.co.id/berita/ek

onomi/syariahekonomi/15/06/25/nqh

y7w-wisata-halal-indonesia-

kalahdibanding-malaysia-dan-

$\underline{\text { thailand }}$

Permadi, L. A., Darwini, S., Retnowati, W., Negara, I. K., \& Septiani, E. (2018).

Persepsi dan Sikap Masyarakat terhadap Rencana Dikembangkannya Wisata Syariah (Halal Tourism) di Provinsi Nusa Tenggara Barat. Amwaluna: Jurnal Ekonomi dan Keuangan Syariah, 2(1), 39-57.

Putri, Winda. Destiana. (2015). Menpar: Halal Tourism Must 'Rahmatan Lil Alamin'. Dipetik dari http://www.republika.co.id: http://www.republika. co.id/berita/gayahidup/travelling/15/ 05/12/no8jis-menpar-wisata-halalharus-rahmatan-lil-alamin

Razzaq, Sherin., Hall, C. Michael., \& Prayag, Girish. (2015). The Capacity of New Zealand to Accommodate the Halal Tourism Market - Or Not. Dipetik Agustus 5, 2015, dari https://canterbury-nz.academia.edu: https://www. academia.edu/12107406/The_capacit y_of_New_Zealand_ to_accommodate_the_halal_ tourism_market_or_not
Rimet. (2019). Sharia Tourism Development Strategy in West Sumatra: SWOT Analysis (Strength, Weakness, Opportunity, Threath). SYARIKAT: Jurnal Rumpun Ekonomi Syariah. Volume 2 Nomor 1, Juni 2019.

Reuters, T., \& Dinar Standard. (2014). State of the Global Islamic Economy 2014-2015 Report. Dubai: Dubai the Capital of Islamic Economy.

Sugiyono. (2012). Quantitative, Qualitative, and Research Methods. Bandung: Alfabeta.

Sofyan, Riyanto. (2012). Sharia Tourism Business Prospects. Jakarta: Republika. https://www.pulaumadura.com/2018/05/30obyek-wisata-di-kabupaten-bangkalan.html 